\title{
THE SHEEP EGG: ENZYMATIC REMOVAL OF THE ZONA PELLUCIDA AND CULTURE OF EGGS IN VITRO
}

\author{
R. M. MOOR* AND R. G. GRAGLE $\dagger$ \\ Laboratory of Genetics, \\ University of Wisconsin, Madison, U.S.A.
}

(Received 24th December 1970, accepted 15th March 1971)

Summary. A total of 429 eggs was used to investigate procedures both for the removal of the zona pellucida and for the culture of sheep eggs in vitro.

The effect of pronase, papain, bromelain, trypsin and $\alpha$-chymotrypsin, on the zonae pellucidae of fertilized and unfertilized eggs was studied in the first series of experiments. All the enzymes were effective in removing the zonae pellucidae from unfertilized eggs. Pronase was the only enzyme that had a significant lytic effect on the zonae of fertilized eggs denuding $34 \%$ of eggs in less than $5 \mathrm{~min}$ and almost all the other eggs within $90 \mathrm{~min}$.

Investigation of some of the factors involved in the successful culture of normal sheep eggs in vitro constituted the second part of the study. Eggs of both the eight- to sixteen-cell and morula stages were cultured for $72 \mathrm{hr}$ in either sheep serum, enriched tissue culture medium 199 or Brinster's medium. The development and viability of the eggs after culture was determined by transferring some eggs to recipient sheep and making accurate cell counts on the remainder. Eggs recovered at the eight-cell stage underwent only one or two cleavage divisions during the 72-hr culture period. These eggs did not develop into foetuses when transferred to the uteri of recipient sheep. On the other hand, the majority of morulae cultured for $72 \mathrm{hr}$ in enriched M199 or sheep serum underwent cleavage and blastulation in vitro. That the cultured blastocysts were normal was demonstrated by their implantation and growth into foetuses when transferred to the uteri of suitable recipients.

\section{INTRODUCTION}

The removal of the zona pellucida and the culture of the eggs in vitro are important steps in procedures such as the production of mouse chimeras by egg fusion (Tarkowski, 1961; Mintz, 1962a). There have, however, been no reliable methods described for the enzymatic removal of the zona pellucida or for the successful culture of sheep eggs in vitro.

* Present address: Agricultural Research Council Unit of Reproductive Physiology and Biochemistry, 307 Huntingdon Road, Cambridge, U.K.

$\dagger$ Present address: Department of Animal and Veterinary Science, Virginia Polytechnic Institute, Blacksburg, Virginia, U.S.A. 
The zona pellucida of the mouse egg can be removed either by mechanical means (Tarkowski, 1961) or by exposing the egg to one of a number of chemical agents, the most effective of which is the proteolytic enzyme pronase (Smithberg, 1953; Mintz, 1962b; Gwatkin, 1964). This enzyme is not, however, an effective means of removing the zonae from the eggs of rats and sheep (Toyoda \& Chang, 1968; Pighills, Hancock \& Hall, 1968). Different proteolytic enzymes have been used in the present study in an attempt to find a suitable chemical means of removing the zona pellucida from the sheep egg.

Most of the work on the culture of mammalian eggs in vitro has concerned mouse eggs. In this species, cultured eggs will develop readily into blastocysts which will then continue to term if transferred to a suitable host animal (see Brinster, 1968). By contrast, sheep eggs develop poorly under conditions in vitro. Eggs placed in culture before the sixteen-cell stage undergo a very limited number of divisions before becoming degenerate (Robinson, 1951; Wintenberger, Dauzier \& Thibault, 1953; Hancock, 1963; Kraemer, 1966; Tervit \& McDonald, 1969; Moore, 1970). Embryos recovered at the morula stage do, however, develop more readily in vitro and some apparently normal blastocysts have been obtained in culture (Wintenberger et al., 1953).

The experiments described in this paper are concerned with the removal of the zona pellucida and the culture of sheep eggs in vitro.

\section{MATERIALS AND METHODS}

The experiments were carried out between October 1968 and March 1969 on eighty Targhee and eighteen Hampshire Down sheep. The occurrence of oestrus was checked once daily using either a vasectomized or a fertile ram according to the experimental group. The day on which oestrus occurred is referred to as Day 0 of the cycle.

All surgical procedures were carried out under sodium pentobarbital anaesthesia, observing aseptic precautions.

\section{Donor sheep}

Superovulation was induced in the donor sheep either by the subcutaneous injection on Day 12 of 150 units PMSG (Ayerst Laboratories) or by the administration of 5 to $15 \mathrm{mg}$ of FsH (Armour Laboratories) given in two to four daily intramuscular injections, starting on the 12th day after oestrus.

The eggs were flushed from the donor's reproductive tract in vivo with either sterile sheep serum or tissue culture medium 199 (M199 Microbiological Associates) using the technique of Hunter, Adams \& Rowson (1955). The eggs were examined microscopically and then kept under an atmosphere of $5 \%$ $\mathrm{CO}_{2}$ and $95 \%$ air in an incubator at $37^{\circ} \mathrm{C}$ pending further experimental manipulation.

\section{Recipient sheep}

Either one or two eggs were transferred to the uteri of forty-eight nonpregnant sheep. The onset of oestrus in the donor and recipient animals was exactly synchronized in every case where eggs were to be transferred directly 
without an intervening period in culture. Cultured eggs, on the other hand, were transferred to recipients that had exhibited oestrus $24 \mathrm{hr}$ after the onset of oestrus in the donor animal; this was to compensate for possible retardation in the development of eggs in culture.

\section{Experimental design}

The work was carried out in two parts and was designed to provide information on (A) the enzymatic removal of the zona pellucida and (B) the conditions required for successful culture of sheep eggs in vitro. The two studies were run concurrently.

A. Enzymatic digestion of the zona pellucida and the viability of the denuded eggs. The effectiveness of five proteolytic enzymes in removing the zonae of fertilized and unfertilized eggs, recovered $72 \mathrm{hr}$ after oestrus, was tested in Exp. 1. The enzymes used and their source, together with the concentration, $\mathrm{pH}$ and osmolarity at which they were tested, are shown in Table 1.

\section{TABLE 1}

ENZYME PREPARATIONS USED FOR THE REMOVAL OF THE ZONA PELLUGIDA FROM SHEEP EGGS

\begin{tabular}{l|c|c|c|l}
\hline \multicolumn{1}{c|}{ Enzyme } & Concentration* & $p H$ & Osmotic pressure $\dagger$ & \multicolumn{1}{|c}{ Source of enzyme } \\
\cline { 2 - 3 } & $0.5 \%$ & $6 \cdot 8$ to $7 \cdot 2$ & 282 & Calbiochem B Grade \\
Pronase & $0.5 \%$ & $5 \cdot 2$ to $5 \cdot 3$ & 300 & Sigma Type II \\
Papain & $0.5 \%$ & $6 \cdot 8$ to $7 \cdot 2$ & 295 & Pfanstiehl \\
Trypsin & $0.5 \%$ & $6 \cdot 8$ to 7.2 & 294 & Worthington \\
$\alpha$-Chymotrypsin & $0.5 \%$ & $5 \cdot 7$ & 297 & Sigma Grade II \\
Bromelain & & & \\
\hline
\end{tabular}

* In Hanks' solution.

$\dagger$ mosmol; average of four or five determinations; average S.D. $=15$ mosmol.

Individual eggs with the appropriate enzyme solution were placed in sterile immunological well-trays (Disposo-Tray, Linboo Chemical Co.) and the eggs were examined repeatedly during the first $15 \mathrm{~min}$ of exposure to the enzyme. Thereafter, each egg was examined every 10 to 15 min until the zona was lost or, failing that, until the egg had been in the enzyme solution for $90 \mathrm{~min}$.

The fertilized eggs were removed from the enzyme solution as rapidly as possible after the loss of the zona, washed in four successive wells containing sheep serum and kept in serum at $37^{\circ} \mathrm{C}$ until required for culture or transfer. The viability of the denuded eggs was determined either under culture conditions in vitro or by transferring the eggs to the uteri of recipient sheep. The eggs were fixed and stained after $72 \mathrm{hr}$ in enriched M199 culture medium. (See Study B for details of culture procedure.)

B. Culture of sheep eggs in vitro. Two of the conditions affecting the development of sheep embryos in vitro, namely the age of the embryo and the nature of the medium used for culture, were investigated in this study. Embryos were recovered from donor sheep at 72 or $120 \mathrm{hr}$ after oestrus and were cultured in micro-drops of medium (100 to $200 \mu \mathrm{l}$ ) placed under mineral oil according to the technique of Brinster (1963). The culture dishes (Falcon plastic) containing 
the embryos were incubated for $72 \mathrm{hr}$ at $37^{\circ} \mathrm{C}$ in an atmosphere of $5 \% \mathrm{CO}_{2}$ and $95 \%$ air.

The three media used in the culture experiments were sheep serum, Brinster's medium (Brinster, 1965) and enriched medium M199. Sheep serum was treated at $56^{\circ} \mathrm{G}$ for $30 \mathrm{~min}$ for complement fixation and then kept frozen at $-10^{\circ} \mathrm{C}$ until required. When at equilibrium under $5 \% \mathrm{CO}_{2}$ in air, the $\mathrm{pH}$ of the serum was between 7.85 and 7.90 and the osmotic pressure was 313 mosmol. No osmotic pressure adjustments were made to compensate for the slight hypertonicity of the serum.

Brinster's medium was prepared just before use, the calcium and magnesium salts being added last to minimize carbonate formation. The enriched M199 medium was prepared by adding $2.0 \mathrm{ml}$ of complement-fixed foetal bovine serum (Microbiological Associates), $0.7 \mathrm{ml}$ of $0.154 \mathrm{M}$-sodium lactate (1 $\mathrm{mg}$ of lactate per $\mathrm{ml}$ of final solution) and $1.1 \mathrm{ml}$ of distilled water to $6.2 \mathrm{ml}$ of M199 to give $10 \mathrm{ml}$ of medium. Both the Brinster's and enriched M199 media were isosmotic (290 mosmol) and under a $5 \% \mathrm{CO}_{2}$ in air atmosphere, had a $\mathrm{pH}$ of $7 \cdot 2$.

Table 2

ENZYMATIC DIGESTION OF THE ZONAE PELLUCIDAE OF FERTILIZED SHEEP EGGS REGOVERED FROM DONOR ANIMALS 72 HR AFTER OESTRUS

\begin{tabular}{l|c|c|ccc}
\hline $\begin{array}{c}\text { Enzyme } \\
\text { preparation }\end{array}$ & $\begin{array}{c}\text { No. of } \\
\text { eggs tested }\end{array}$ & $\begin{array}{c}\text { No. of } \\
\text { donor sheep }\end{array}$ & \multicolumn{3}{|c}{$\begin{array}{c}\text { No. of donors whose eggs } \\
\text { were denuded in: } \\
\text { ing }\end{array}$} \\
\hline Pronase & 70 & 38 & 13 & 23 & 2 \\
Papain & 7 & 6 & 1 & 0 & 5 \\
Bromelain & 8 & 6 & 1 & 0 & 5 \\
Trypsin & 9 & 7 & 0 & 1 & 6 \\
$\alpha$-Chymotrypsin & 8 & 5 & 0 & 2 & 3 \\
\hline
\end{tabular}

A careful microscopic examination was made of all the eggs after $72 \mathrm{hr}$ in culture. Those that had undergone cleavage in vitro were either fixed and stained and the number of nuclei in each egg counted, or else the eggs were transferred to the uteri of recipient ewes. Normal (uncultured) eggs as controls were likewise transferred to recipient animals and the percentages of eggs developing in each group were compared.

\section{RESULTS}

A total of 351 fertilized eggs and seventy-eight unfertilized eggs were recovered from the donor animals.

A. Enzymatic digestion of the zona pellucida and the viability of denuded eggs

The effectiveness of various proteolytic enzymes in removing the zona pellucida of the fertilized sheep egg is shown in Table 2. Of the five proteolytic enzymes used, only pronase consistently removed the zona pellucida from the eggs. However, it was in only $34 \%$ of the donors in the 'pronase group' that 
the fertilized eggs were denuded relatively rapidly: the zonae were removed from the eggs of $26 \%$ of the donors in less than $3 \mathrm{~min}$ and from the eggs of $8 \%$ of the donors in 5 to $15 \mathrm{~min}$. An exposure to pronase of more than $45 \mathrm{~min}$ was required to denude the eggs of the other donors in this group. Even after 90 min, most of the eggs exposed to papain, bromelain, trypsin or $\alpha$-chymotrypsin still had intact zonae.

Perhaps the most striking feature of this experiment was the consistent manner in which all the eggs from the same donor responded to pronase. Either all the eggs from one animal lost their zonae very rapidly or they all required a considerable period in pronase before becoming devoid of their zonae. The importance of maternal factors in determining the speed with which pronase removed the zona pellucida was examined further in a second trial. Four sheep whose eggs had been denuded rapidly in the first experiment were again injected with PMSG and then used as donors for a second time. As

TABLE 3

ENZYMATIC DIGESTION OF THE ZONAE PELLUCIDAE OF UNFERTILIZED SHEEP EGGS REGOVERED FROM DONOR ANIMALS 72 HR AFTER OESTRUS

\begin{tabular}{l|c|c|ccc}
\hline $\begin{array}{c}\text { Enzyme } \\
\text { preparation }\end{array}$ & $\begin{array}{c}\text { No. of } \\
\text { eggs tested }\end{array}$ & $\begin{array}{c}\text { No. of } \\
\text { donor sheep }\end{array}$ & \multicolumn{3}{|c}{$\begin{array}{c}\text { No. of donors whose eggs } \\
\text { were denuded in: } \\
15 \text { to } 90 \text { min }\end{array}$} \\
\hline Pronase & 16 & 8 & 7 & 1 & 0 \\
Papain & 16 & 9 & 5 & 2 & 2 \\
Bromelain & 16 & 8 & 3 & 3 & 2 \\
Trypsin & 15 & 6 & 1 & 3 & 1 \\
$\alpha$-Chymotrypsin & 15 & 7 & 0 & 6 & 1 \\
\hline
\end{tabular}

before, all the eggs from three of these donors were denuded very rapidly ( 1 to $3 \mathrm{~min}$ ) while the eggs from the fourth donor were denuded in 15 to $25 \mathrm{~min}$. This trial suggests that the zonae of eggs from some donors are less resistant to the action of pronase than eggs from other sheep.

It will be seen from Table 3 that unfertilized eggs, flushed from the uteri of sheep $72 \mathrm{hr}$ after oestrus, are highly susceptible to rapid enzymatic digestion of the zona pellucida. Unfertilized eggs were denuded fairly rapidly and consistently by all five enzymes, whereas fertilized eggs were little affected by bromelain, papain, trypsin and $\alpha$-chymotrypsin.

In an attempt to test the viability of the eggs after removal of the zona, fifteen denuded eggs were transferred to the uteri of recipient ewes and two groups of fourteen eggs were cultured for $72 \mathrm{hr}$, one group in homologous sheep serum and the other in enriched M199 medium. Cleavage did not occur in any of the denuded eggs in culture and none of the eggs transferred to the uteri of recipients developed into foetuses. The structural integrity of the blastomeric mass was retained in only twelve of the twenty-eight cultured eggs; in the other sixteen denuded eggs, the blastomeres became dissociated within $48 \mathrm{hr}$.

B. Culture of sheep embryos in vitro

The degree to which sheep eggs develop after culture in vitro for $72 \mathrm{hr}$ is shown in Table 4. 
TABLE 4

THE INFLUENCE OF THE AGE OF THE EGG AND THE TYPE OF GULTURE MEDIUM ON THE DEVELOPMENT OF EGGS AND MORULAE GULTURED FOR $72 \mathrm{HR}$ in vitro

\begin{tabular}{|c|c|c|c|c|c|}
\hline \multirow{2}{*}{$\begin{array}{l}\text { Interval } \\
\text { from } \\
\text { oestrus } \\
\text { to egg } \\
\text { recovery } \\
(\mathrm{hr})\end{array}$} & \multirow{2}{*}{$\begin{array}{l}\text { Culture } \\
\text { medium }\end{array}$} & \multirow{2}{*}{$\begin{array}{c}\text { No. } \\
\text { of eggs } \\
\text { cultured }\end{array}$} & \multicolumn{3}{|c|}{ Embryonic development after $72 \mathrm{hr}$ in vitro } \\
\hline & & & $\begin{array}{c}\text { No } \\
\text { development }\end{array}$ & $\begin{array}{c}\text { Arrested } \\
\text { development }\end{array}$ & $\begin{array}{c}\text { Normal } \\
\text { development }\end{array}$ \\
\hline $\begin{array}{r}72 \\
72 \\
72 \\
120 \\
120 \\
120\end{array}$ & $\begin{array}{l}\text { M199 } \\
\text { Brinster's medium } \\
\text { Sheep serum } \\
\text { M199 } \\
\text { Brinster's medium } \\
\text { Sheep serum }\end{array}$ & $\begin{array}{l}82 \\
30 \\
15 \\
48 \\
15 \\
22\end{array}$ & $\begin{array}{r}31 \\
16 \\
6 \\
12 \\
13 \\
7\end{array}$ & $\begin{array}{r}51 \\
14 \\
9 \\
8 \\
2 \\
3\end{array}$ & $\begin{array}{r}0 \\
0 \\
0 \\
28 \\
0 \\
12\end{array}$ \\
\hline
\end{tabular}

None of the 127 fertilized eggs recovered $72 \mathrm{hr}$ after oestrus underwent normal cleavage and blastulation in culture. Development was arrested after one or, at most, two cleavage divisions in seventy-four eggs; no development occurred in the other fifty-three cultured eggs. There was no indication that the three culture media differed in the degree to which they could support the early development of the eight- to sixteen-cell sheep egg.

Morulae recovered on Day 5 underwent apparently normal development both in enriched M199 and in sheep serum but not in Brinster's medium. Clear disc and cavity formation occurred in $73 \%$ (fifty-one out of seventy) of the morulae cultured in M199 or sheep serum. Because of an apparent underdevelopment of the embryonic disc, eleven of the cultured blastocysts were classified as having suffered 'arrested development'. Morulae recovered on Day 5 and placed in Brinster's medium did not undergo more than one cleavage division during the $72 \mathrm{hr}$ in culture.

The shedding of the zona pellucida in culture occurs 24 to $48 \mathrm{hr}$ later than in utero and in an apparently different manner; the characteristic hatching of the blastocyst in vitro and the shedding of the zona in vivo is illustrated in Pl. 1, Figs $1 \mathrm{a}$ and $\mathrm{b}$ and Fig. 2. An inability to shed the zona probably contributed

TABLE 5

DEVELOPMENT OF GULTURED AND NON-GULTURED EGGS FOLLOWING TRANSFER TO THE UTERI OF RECIPIENT SHEEP

\begin{tabular}{|c|c|c|c|c|c|c|}
\hline \multirow{2}{*}{$\begin{array}{l}\text { Treatment } \\
\text { of eggs } \\
\text { before } \\
\text { transfer }\end{array}$} & \multirow{2}{*}{$\begin{array}{l}\text { Interval } \\
\text { from } \\
\text { oestrus } \\
\text { to egg } \\
\text { recovery } \\
\text { (hr) }\end{array}$} & \multirow[b]{2}{*}{$\begin{array}{l}\text { Culture } \\
\text { medium }\end{array}$} & \multirow[b]{2}{*}{$\begin{array}{l}\text { Total no. of } \\
\text { recipients }\end{array}$} & \multirow[b]{2}{*}{$\begin{array}{l}\text { No. of eggs } \\
\text { transferred }\end{array}$} & \multicolumn{2}{|c|}{$\begin{array}{l}\text { Results of embyro } \\
\text { transplantation }\end{array}$} \\
\hline & & & & & $\begin{array}{c}\text { Recipients } \\
\text { pregnant }\end{array}$ & $\begin{array}{l}\text { No. of } \\
\text { foetuses }\end{array}$ \\
\hline $\begin{array}{l}\text { Not cultured } \\
72 \mathrm{hr} \text { culture } \\
72 \mathrm{hr} \text { culture } \\
72 \mathrm{hr} \text { culture }\end{array}$ & $\begin{array}{r}72 \\
72 \\
120 \\
120\end{array}$ & $\begin{array}{l}\text { M199- } \\
\text { M199 } \\
\text { Sheep serum }\end{array}$ & $\begin{array}{r}20 \\
7 \\
9 \\
4\end{array}$ & $\begin{array}{r}30 \\
15 \\
14 \\
8\end{array}$ & $\begin{array}{l}8 \\
0 \\
3 \\
1\end{array}$ & $\begin{array}{r}10 \\
0 \\
3 \\
1\end{array}$ \\
\hline
\end{tabular}


PLATE 1


FIG. la, b. Two morulae recovered from the uterus of a sheep on the 6 th day after ocstrus. Notice the characteristic rupture of the zona pellucida which precedes the shedding of the zona in utero.

FIG. 2. The hatching of a blastocyst from its zona pellucida during development in vitro. In culture, the zona cracks slightly and the blastocyst is extruded through the resultant opening. This method of zona shedding is slower and contrasts markedly with the loss of the zona in vivo (shown in Fig. 1).

Frc. 3. A thinned zona pellucida is visible surrounding a fully expanded blastocyst.

FIG. 4. An early stage in the collapse of a blastocyst that had undergone blastulation and expansion but had failed to shed its zona in vitro. 
largely to the degeneration of most of the '5-day' morulae that failed to develop into blastocysts during culture in enriched M199 medium or in sheep serum. Before degeneration, these embryos underwent blastulation and expanded to fill the entire intrazonal space (Pl. 1, Fig. 3). After about $48 \mathrm{hr}$ in culture, the early blastulae collapsed, leaving a thick zona and a contracted cell mass in the centre of the egg (Pl. 1, Fig. 4).

The viability of the cultured embryos was determined by transferring them to the uteri of suitable recipient sheep (Table 5). None of the eggs recovered $72 \mathrm{hr}$ after oestrus, cultured for 3 days and then transferred to host animals, developed into foetuses. On the other hand, four of twenty-two morulae recovered on Day 5 and cultured in enriched M199 or sheep serum for $72 \mathrm{hr}$ developed into normal foetuses after transfer to recipient sheep. This disappointingly low survival of cultured eggs in vivo was matched by an almost equally low number of successful transfers of non-cultured eggs; only ten out of thirty eggs developed into foetuses after the direct transfer of eggs from donor to recipient ewes.

\section{DISGUSSION}

These experiments highlight some of the major difficulties associated with the enzymatic removal of the zona pellucida and the development of sheep eggs in vitro. The only proteolytic enzyme that had a significant lytic effect on the zona pellucida of the fertilized sheep egg was pronase. A $0.5 \%$ solution of this enzyme removed the zonae from the eggs of only about one third of the donors within the 3- to 5-min period required to denude the mouse egg. Moreover, the established methods of culturing eggs in vitro are not suitable for the normal development of the eight- to sixteen-cell sheep egg, but are suitable for the development of morulae in culture.

In 1956, Chang \& Hunt, working with rats, rabbits and hamsters, reported that the zonae pellucidae of unfertilized eggs were much more affected by proteolytic enzymes than were their fertilized counterparts. It is clear from our experiments that the zonae of unfertilized sheep eggs are similarly very much more rapidly denuded by proteolytic enzymes than are the zonae of fertilized eggs. The rapid enzymatic digestion of the zonae of unfertilized eggs and the marked resistance of the zona to the same enzyme after fertilization is probably a reflection of changes in the chemical structure of the zona after sperm penetration. A factor of importance in determining the susceptibility of the zonae of fertilized eggs to digestion by pronase appears to be of maternal origin and influences all the eggs from one donor in a similar manner.

We have observed that the blastomeres often separate in culture after removal of the zona pellucida from the eight-cell egg. This blastomere separation is not necessarily a result of enzyme treatment since Pighills et al. (1968) noted similar blastomeric separation of eight- to sixteen-celled eggs after mechanical removal of the zona. In our experiments, it was found that eggs collected at the eight-cell stage, denuded with pronase and immediately transferred to a suitable recipient, failed to develop in utero. Morulae which were mechanically denuded before transplantation also failed to develop in the 
uteri of recipient ewes (Pighills et al., 1968). However, these authors found that morulae without zonae can survive and develop normally in utero if the denuded eggs are first placed in culture for $24 \mathrm{hr}$ before being transferred to host sheep.

It is essential to adopt a critical end-point when assessing embryonic development in vitro. We have used two criteria to assess the development of sheep embryos after culture in vitro. Firstly, some of the eggs that developed furthest in vitro were transferred to suitable recipient sheep and their subsequent development and growth were studied. All the other embryos were fixed, stained and examined microscopically after culture. The accurate nuclear counts made possible by this technique were adopted as a critical second method of assessing embryonic development in vitro. It is clear that we, like other workers (Robinson, 1951; Wintenberger et al., 1953; Hancock, 1963; Kraemer, 1966; Tervit \& McDonald, 1969; Moore, 1970) cannot sustain the development of eight-cell sheep eggs for $72 \mathrm{hr}$ in vitro. The total failure of such eggs to develop normally in culture, despite the use by a number of investigators of a wide variety of techniques and culture media, leads one to suggest that a specific factor might be necessary for the development of the sheep egg at this stage. For example, Krishnan \& Daniel (1967) reported that a uterine substance, blastokinin, is required for the normal development of rabbit eggs. However, if a similar substance is necessary for the development of eight-cell sheep eggs then it cannot be a specific uterine factor since these eggs develop normally when placed in the oviducts of rabbits (Averill, Adams \& Rowson, 1955). The morula, unlike the eight-cell egg, undergoes rapid cleavage and blastulation in vitro. The normality of the blastocysts formed in culture was demonstrated by their ability to implant, and their subsequent growth and development when transferred to the uteri of suitable recipient sheep.

\section{ACKNOWLEDGMENTS}

We are grateful to Dr L. E. Casida and Dr W. H. Stone for making animals, facilities and materials available for this study, and to Sandra Bates and Nancy Korda for technical assistance.

This constitutes Paper No. 1419 from the Genetics Laboratory, University of Wisconsin and is published with the approval of the Director of the Research Division of the College of Agricultural and Life Sciences. The study was supported in part by The Ford Foundation Grant No. 63-505, and in part by the NIH Grant No. AI/03204.

\section{REFERENCES}

Averill, R. L. W., Adams, C. E. \& Rowson, L. E. A. (1955) Transfer of mammalian ova between species. Nature, Lond. 176, 167.

BRINster, R. L. (1963) A method for in vitro cultivation of mouse ova from two-cell to blastocyst. Expl Cell Res. 32, 205.

Brinster, R. L. (1965) Studies on the development of mouse embryos in vitro. III. The effect of fixed nitrogen source. J. exp. Zool. 158, 69.

Brinster, R. L. (1968) In vitro culture of mammalian embryos. F. Anim. Sci. 27, Suppl. 1, 1.

Chang, M. C. \& Hunt, D. M. (1956) Effects of proteolytic enzymes on the zona pellucida of fertilized and unfertilized mammalian eggs. Expl Cell Res. 11, 497.

GWATkin, R. B. L. (1964) Effect of enzymes and acidity on the zona pellucida of the mouse egg before and after fertilization. F. Reprod. Fert. 7, 99. 
Hancock, J. L. (1963) Survival in vitro of sheep eggs. Anim. Prod. 5, 237.

Hunter, G. L., Adams, C. E. \& Rowson, L. E. A. (1955) Interbreed ovum transfer in sheep. F. agric. Sci., Camb. 46, 143.

Kraemer, D. C. (1966) A study of in vitro fertilization and culture of ovine ova. Diss. Abstr. 27, 285.

KRISHNAN, R. S. \& Daniel, J. J., JR (1967) 'Blastokinin': inducer and regulator of blastocyst development in the rabbit uterus. Science, $\mathcal{N} . Y .158,490$.

Mintz, B. (1962a) Formation of genotypically mosaic mouse embryos. Am. Zool. 2, 432.

Mrntz, B. (1962b) Experimental study of the developing mammalian egg: removal of the zona pellucida. Science, N.Y. 138, 594.

Moore, N. W. (1970) Preliminary studies on in vitro culture of fertilized sheep ova. Aust. F. biol. Sci. 23, 721.

Pighilzs, E., Hancock, J. L. \& Hall, J. G. (1968) Attempted induction of chimaerism in sheep. F. Reprod. Fert. 17, 543.

Robinson, T. J. (1951) The control of fertility in sheep. II. The augmentation of fertility by gonadotrophin treatment of the ewe in the normal breeding season. 7. agric. Sci., Camb. 41, 6.

Smithrerg, M. (1953) The effect of different proteolytic enzymes on the zona pellucida of mouse ova. Anat. Rec. 117, 554.

Tarkowski, A. K. (1961) Mouse chimaeras developed from fused eggs. Nature, Lond. 190, 857.

Tervit, H. R. \& MCDonald, M. F. (1969) Abnormalities and dimensions of ova from New Zealand Romney ewes. $\mathcal{N} . Z$. Jl agric. Res. 12, 21.

Toyoda, Y. \& Chang, M. C. (1968) Sperm penetration of rat eggs in vitro after dissolution of the zona pellucida by chymotrypsin. Nature, Lond. $220,589$.

Wintenberger, S., Dauzier, L. \& Thibault, C. (1953) Le développement in vitro de l'oeuf de la brebis et de celui de la chèvre. C.r. Séanc. Soc. Biol. 147, 1971. 